\title{
Pharmacological Studies of FUT-175, Nafamostat Mesilate V. Effects on the Pancreatic Enzymes and Experimental Acute Pancreatitis in Rats
}

\author{
Masahiro IWAKI, Yoshitaka INO*, Akemi MOTOYOSHI, \\ Masayuki OZEKI, Takuo SATO, Masateru KURUMI and Takuo AOYAMA \\ Research Laboratories, Torii \& Co., Ltd., \\ 3-14-3 Minamiyawata, Ichikawa 272, Japan \\ Accepted February 17, 1986
}

\begin{abstract}
Effects of FUT-175 on the pancreatic enzymes in vitro and in vivo in the enterokinase-induced experimental acute pancreatitis were investigated, and they were compared with those of gabexate and aprotinin. In in vitro experiments, FUT-175 inhibited the pancreatic protease activities 10 to 100 times more potently than gabexate. Furthermore. FUT-175 inhibited the enterokinase activity. Unlike aprotinin. FUT-175 inhibited $\alpha_{2}$-macroglobulin bound trypsin activity as well as free trypsin. In in vivo experiments, at doses of $0.5-50 \mu \mathrm{g} / \mathrm{kg} / \mathrm{min}$, FUT-175 suppressed the elevated protease activities in the experimental acute pancreatitis more potently than gabexate. Differently from the action of aprotinin, FUT-175 suppressed trypsin activities both in the pancreas and in the plasma to the same extent. Furthermore, FUT-175 reduced the mortality of rats in the experimental acute pancreatitis in a dose-dependent manner. These data strongly support that FUT-175 is clinically useful in the therapy of acute pancreatitis.
\end{abstract}

FUT-175, 6-amidino-2-naphthyl pguanidinobenzoate dimethanesulfonate (nafamostat mesilate), has been shown to have potent inhibitory effects on serine proteases such as trypsin, kallikrein, C1r. $\mathrm{C} 1 \overline{\mathrm{s}}$, thrombin and plasmin $(1,2)$. Previously, we reported that FUT-175 reduced the mortality of rats and rabbits in the experimental acute pancreatitis induced by trypsin (3) and suggested that FUT-175 might be clinically useful in the therapy of acute pancreatitis.

Creutzfeldt and Schmidt (4) have postulated that the activation of trypsinogen by enterokinase and of a series of pancreatic enzymes in turn by the activated trypsin is one of the most important steps in the pathogenesis of pancreatitis. Pancreatic enzymes cause tissue damages including interstitial edema, hemorrhage and necrosis in the pancreas (5), and they also cause

* To whom correspondence should be addressed. hypotension and shock after they are released into the blood (6). In consideration of such processes and the etiology of human pancreatitis, it is important to examine the effect of drugs on protease activities in the pancreas and in the blood in experimental acute pancreatitis.

Thus, the present study was carried out primarily for the purpose of evaluating the effect of FUT-175 on pancreatic enzymes in the pancreas in experimental acute pancreatitis.

\section{Materials and Methods}

\section{Chemicals}

Drugs used were aprotinin (Trasylol'B), Bayer; Sigma), gabexate mesilate (FOY Ono Pharm.), soybean trypsin inhibitor (SBTI, Sigma) and $\alpha_{2}$-macroglobulin (Boehringer Mannheim Yamanouchi, Inc.). Substrates used were tosyl-L-arginine methylester (TAME, Protein Research Foundation), benzoyl-L-arginine ethylester 
(BAEE, Protein Research Foundation), tbutoxycarbonyl - $L$ - phenylalanyl - $L$ - seryl - $L$ arginine 4-methylcoumaryl-7-amide (BocPheSerArgMCA, Protein Research Foundation), L-phosphatidylcholine (Sigma) and azocasein (Sigma). Other materials used were trypsin (Sigma), phospholipase $A_{2}$ (Sigma). sheep erythrocytes (Nippon Bio-Test Lab., Inc.), enterokinase (Sigma), sodium taurocholate (Difco), amylase assay kit (Amylase Test Wako ${ }^{\circledR}$, Wako) and protein assay kit (Bio-Rad protein assay $\mathrm{kit}^{\mathrm{R}}$, BioRad).

\section{Animals}

Male Sprague-Dawley rats weighing 200$250 \mathrm{~g}$ were obtained from Japan Charles River Co. for all the experiments.

\section{In vitro experiments}

1) The pancreatic enzyme preparation: The pancreas obtained from a normal rat was homogenized to prepare a $10 \%$ suspension in $10 \mathrm{mM}$ Tris- $\mathrm{HCl}$ buffer ( $\mathrm{pH}$ 8.5) containing $0.1 \%$ Triton $X-100$ and $150 \mathrm{mM} \mathrm{NaCl}$. The homogenate was centrifuged at $10,000 \times \mathrm{g}$ for 20 min at $4^{\circ} \mathrm{C}$. The supernatant was used as the pancreatic enzyme preparation. Protein content of the preparation was determined using the Bio-Rad protein assay kit ${ }^{\mathbb{R}}$.

2) Effect on the pancreatic enzyme activities: The pancreatic enzyme preparation was activated by enterokinase according to the method of Barns and Elislie (7). In brief. $5 \mathrm{ml}$, final volume, of the mixture consisting of the pancreatic enzyme preparation. $5 \mathrm{mg}$ of enterokinase, $50 \mathrm{mM} \mathrm{CaCl}_{2}$ and $130 \mathrm{mM}$ $\mathrm{NaCl}$ in $50 \mathrm{mM}$ Tris- $\mathrm{HCl}$ buffer ( $\mathrm{pH} 7.4$ ) was incubated at $30^{\circ} \mathrm{C}$ for $3 \mathrm{hr}$ in the presence or absence of test drugs. Activities in the enterokinase-activated pancreatic enzyme preparation were measured as follows: In the assay using BocPheSerArgMCA as the substrate for trypsin, the activated enzyme preparation and $50 \mathrm{mM}$ Tris- $\mathrm{HCl}$ buffer $(\mathrm{pH}$ 7.4) containing 0.1 «mole of BocPheSerArgMCA with or without test drugs were mixed to obtain a final volume of $1 \mathrm{ml}$. After the reaction mixture was incubated at $37^{\circ} \mathrm{C}$ for $15 \mathrm{~min}, 2 \mathrm{ml}$ of $15 \%$ acetic acid was added. and the fluorescence of aminomethylcoumarin released from the substrate was measured at Ex $380 \mathrm{~nm}$ and Em $460 \mathrm{~nm}$ on a fluorophotometer (Hitachi, Model MPF-3). In the assay using TAME as an ester-type synthetic substrate, the activated enzyme preparation and $50 \mathrm{mM}$ Tris- $\mathrm{HCl}$ buffer $(\mathrm{pH} 7.4)$ containing 10 \%mole of TAME with or without test drugs were mixed to obtain a final volume of $1 \mathrm{ml}$.

After the reaction mixture was incubated at $37^{\circ} \mathrm{C}$ for $30 \mathrm{~min}$, the residual TAME was determined by Hestrin's method as modified by Roberts (8). In the assay using azocasein as a natural substrate, the activated enzyme preparation and $50 \mathrm{mM}$ Tris- $\mathrm{HCl}$ buffer $(\mathrm{pH}$ 7.4) containing $5 \mathrm{mg}$ azocasein with or without test drugs were mixed to obtain a final volume of $1 \mathrm{ml}$. After the reaction mixture was incubated at $37^{\circ} \mathrm{C}$ for $30 \mathrm{~min}, 1.5 \mathrm{ml}$ of $15 \%$ trichloroacetic acid was added, and the mixture was centrifuged at $1,800 \times \mathrm{g}$ for 10 $\min$ at $4{ }^{\circ} \mathrm{C}$. The absorbance of the supernatant was determined at $440 \mathrm{~nm}$ on a spectrophotometer (Hitachi, Model 100-21).

3) Effect on the enterokinase activity: Enterokinase, $1 \mathrm{mg}$, and 10 \%mole of BAEE were added to $0.67 \mathrm{M}$ phosphate buffer $(\mathrm{pH}$ 5.6) containing test drugs to obtain a final volume of $1 \mathrm{ml}$. After the reaction mixture was incubated at $37^{\circ} \mathrm{C}$ overnight, the residual BAEE was determined by Hestrin's method (8).

4) Effect on the $\boldsymbol{a}_{2}$-macroglobulin-trypsin complex: Trypsin, $0.2 \mu \mathrm{g}$, and $200 \mu \mathrm{g}$ of $\alpha_{2}-$ macroglobulin were dissolved in $0.4 \mathrm{ml}$ of $5 \mathrm{mM}$ Tris- $\mathrm{HCl}$ buffer ( $\mathrm{pH} 7.4$ ) containing $125 \mathrm{mM} \mathrm{NaCl}$, and the mixture was incubated at $37^{\circ} \mathrm{C}$ for $30 \mathrm{~min}$ to obtain the $\alpha_{2}$ macroglobulin-trypsin complex. To the mixture, $10 \mu \mathrm{g}$ of SBTI was added as an inhibitor of excess free trypsin, and $10 /$ mole of TAME was added as the substrate. The mixture, a final volume of $1 \mathrm{ml}$, was incubated at $37^{\circ} \mathrm{C}$ for $30 \mathrm{~min}$ in the presence of test drugs. The residual TA.ME was determined by Hestrin's method (8).

\section{In vivo experiments}

1) Induction of experimental acute pancreatitis: Experimental acute pancreatitis was induced in rats by the technique described by Hansson et al. (9) with some modifications. The animals which had been fasted overnight were anesthetized with 35 $\mathrm{mg} / \mathrm{kg}$ of an intravenous injection of pentobarbital sodium. The common bile duct was 


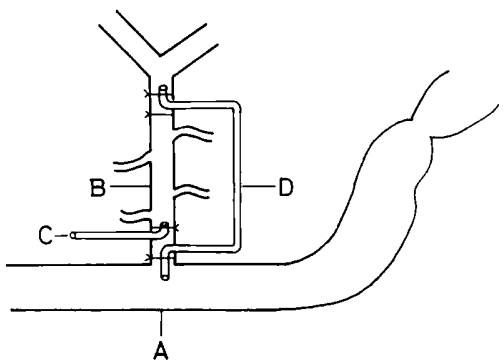

Fig. 1. Schiema for induction of experimental acute pancreatitis. One-tenth $\mathrm{ml}$ of a mixture containing enterokinase and sodium taurocholate was injected through polyethylene tube $\mathrm{C}$. After that, tube $\mathrm{C}$ was removed, and the abdomen was closed. $A$ : duodenum, B: common bile duct, $\mathrm{C}$ : polyethylene tube through which enterokinase and sodium taurocholate were injected, and D: bypass-tube for bile secretion.

exposed through a midline abdominal incision. The polyethylene tube (PE-10) was inserted into the common bile duct as shown in Fig. 1. The pancreatitis was induced by 0.1 $\mathrm{ml}$ of a mixture containing enterokinase (10 $\mathrm{mg}$ ) and sodium taurocholate $(2 \mathrm{mg})$. After the injection, the common bile duct was ligated, and the polyethylene tube $\mathrm{C}$ was removed. Then, the abdomen was closed using Michel clips.

2) Effect on the enzyme activities in the pancreas and plasma: Groups of 6 rats were used. The intravenous infusion $(0.081 \mathrm{ml} /$ min) of each drug dissolved in $5 \%$ glucose solution was started $10 \mathrm{~min}$ prior to the induction of acute pancreatitis, and the infusion was maintained for 100 min using an infusion pump (Harvard. Model 931). After $3 \mathrm{hr}$, the pancreas was removed and homogenized to prepare a $10 \%$ suspension in $50 \mathrm{mM}$ Tris- $\mathrm{HCl}$ buffer ( $\mathrm{pH} \mathrm{7.4)} \mathrm{containing}$ $50 \mathrm{mM} \mathrm{CaCl}_{2}$ and $126 \mathrm{mM} \mathrm{NaCl}$. Each specimen was centrifuged at $10,000 \times \mathrm{g}$ for $20 \mathrm{~min}$ at $4^{\circ} \mathrm{C}$. The protein content of the supernatant was adjusted to $10 \mathrm{mg}$ of protein/ $\mathrm{ml}$, and the supernatant thus obtained was used as the pancreatic enzyme preparation. Blood samples were obtained by cardiac puncture at the same time when the pancreas was obtained and were centrifuged at 1.800 $\times \mathrm{g}$ for $10 \mathrm{~min}$. The resulting supernatant was used as the plasma enzyme preparation. The protease activities in the pancreatic enzyme preparation were measured as described in 3-2) using BocPheSerArgMCA, TAME and azocasein as substrates. The phospholipase $\mathrm{A}_{2}$ activity in the pancreatic enzyme preparation was estimated as follows: The $0.2 \mathrm{ml}$ mixture, total volume, consisting of pancreatic enzyme preparation, $0.05 \mathrm{mg}$ phosphatidylcholine, $1.25 \times 10^{7}$ sheep erythrocytes and $50 \mathrm{mM}$ Tris- $\mathrm{HCl}$ buffer $(\mathrm{pH} 7.4)$ containing $50 \mathrm{mM} \mathrm{CaCl}_{2}$ and $126 \mathrm{mM} \mathrm{NaCl}$ was incubated on a microtiter plate $(8 \times 12$ cells) at room temperature overnight. The activity was calculated from the minimum dilution of the pancreatic enzyme preparation at which no hemolysis occurred. The trypsin activity in the plasma was measured as described in 3-2) using BocPheSerArgMCA as substrate. The amylase activity in the plasma was determined by using an amylase assay kit.

3) Effect on the mortality: Groups of 12 rats were used. The acute pancreatitis was induced as described in 4-1) except that the dose of sodium taurocholate was $4 \mathrm{mg}$. The intravenous infusion of test drug solution $(0.081 \mathrm{ml} / \mathrm{min})$ was started $10 \mathrm{~min}$ prior to induction of the pancreatitis and continued for $100 \mathrm{~min}$, using an infusion pump. The mortality in each group was observed daily for 3 days after induction of the pancreatitis.

4) Statistical analysis: Statistical significance was evaluated using Student's $t$-test and the $x^{2}$-test.

\section{Results}

\section{In vitro experiments}

1) Effect on the pancreatic enzymes: The substrates used, i.e., BocPheSerArgMCA, TAME and azocasein, were found not to be cleaved by the pancreatic enzyme preparation without being activated by enterokinase and by enterokinase itself, either, under the conditions of the present experiments (data not shown).

As shown in Table 1. FUT-175 inhibited the protease activities in the pancreatic enzyme preparation regardless of being added to pancreatic enzyme preparation after or during activation by enterokinase, although aprotinin exerted somewhat less potent activity when added during activation than when added after activation. Gabexate also 
Table 1. Inhibitory effects of FUT-175, gabexate and aprotinin on the pancreatic enzymes

Drug

FUT -175 a)

Gabexate

b)

Aprotinin
a)
b)

\begin{tabular}{cc} 
IC50 $(\mathrm{M})$ & \\
\hline TAME & Azocasein \\
\hline $2.2 \times 10^{-7}$ & $6.5 \times 10^{-7}$ \\
$3.4 \times 10^{-7}$ & $3.3 \times 10^{-7}$ \\
$3.8 \times 10^{-5}$ & $9.2 \times 10^{-6}$ \\
$>10^{-4}$ & $>10^{-4}$ \\
9.6 & 13 \\
28 & 30
\end{tabular}

a) The mixture of pancreatic enzyme preparation $(0.9 \mathrm{mg}$ protein) and enterokinase $(5 \mathrm{mg})$ was incubated at $30^{\circ} \mathrm{C}$ for $3 \mathrm{hr}$. After that, the protease activity of activated pancreatic enzyme was measured in the presence of each drug. b) The mixture of pancreatic enzyme preparation ( $0.8 \mathrm{mg}$ protein) and enterokinase $\left(5 \mathrm{mg}\right.$ ) was incubated at $30^{\circ} \mathrm{C}$ for $3 \mathrm{hr}$ in the presence of each drug. After that, the protease activity of activated pancreatic enzyme was measured. Each value represents the concentration of the drug required for $50 \%$ inhibition of enzyme activity. $† \mathrm{KIU} / \mathrm{ml}$

Table 2. Inhibitory effects of FUT-175, gabexate and aprotinin on the enterokinase activity

\begin{tabular}{clc}
\hline Drug & 1 C50 (M) \\
\cline { 2 - 3 } & FUT-175 & $1.5 \times 10^{-6}$ \\
Gabexate & $>10^{-4}$ \\
& Aprotinin & 4000 \\
\hline
\end{tabular}

The mixture of enterokinase and BAEE was incubated at $37^{\circ} \mathrm{C}$ overnight in the presence of drugs. Each value represents the concentration of the drug required for $50 \%$ inhibition of enzyme activity. $\dagger \mathrm{KIU} / \mathrm{ml}$

inhibited the protease activities in the enterokinase-activated enzyme preparation with a potency of 10 to 100 times less compared with FUT-175, whereas it exhibited no inhibitory effects at concentrations up to $10^{-4} \mathrm{M}$ when added to the preparation during activation by enterokinase.

2) Effect on the enterokinase activity: FUT-175 inhibited the enterokinase activity with an IC50 value of $1.5 \times 10^{-6} \mathrm{M}$. Aprotinin also inhibited the enterokinase activity with an IC50 value of $4000 \mathrm{KIU} / \mathrm{ml}$. However, no inhibitory effect was found with gabexate (Table 2).

3) Effect on the $\boldsymbol{\alpha}_{2}$-macroglobulintrypsin complex: FUT-175 and gabexate, which are synthetic low-molecular protease inhibiting drugs, reduced the activity of $\alpha_{2-}$ macroglobulin-trypsin complex as well as free trypsin, but aprotinin. which is a protease inhibiting drug of a large molecular size. showed weaker inhibitory effect on the activity of the complex than on that of free trypsin (Fig. 2).

\section{In vivo experiments}

1) Effect on enzyme activity in the pancreas in experimental acute pancreatitis: In rats of the normal group, which were injected saline into the pancreas instead of the mixture of enterokinase and sodium taurocholate, almost no activities of proteases and phospholipase $A_{2}$ were detected, but moderate edematous swelling was observed in the pancreas by macroscopic observation. On the other hand, in rats of the control group. in which pancreatitis was induced with enterokinase and sodium taurocholate, activities of protease and phospholipase $A_{2}$ were clearly elevated, and the typical pattern of the acute pancreatitis such as marked edematous swelling and hemorrhage was found by macroscopic observation.

FUT-175 decreased protease activities in the pancreas in the acute pancreatitis. Namely, FUT-175 showed a slight suppression on the trypsin activity measured with BocPheSerArgMCA at doses of 0.5 and $5 \mu \mathrm{g} / \mathrm{kg} / \mathrm{min}$ and a significant suppression at a dose of 50 


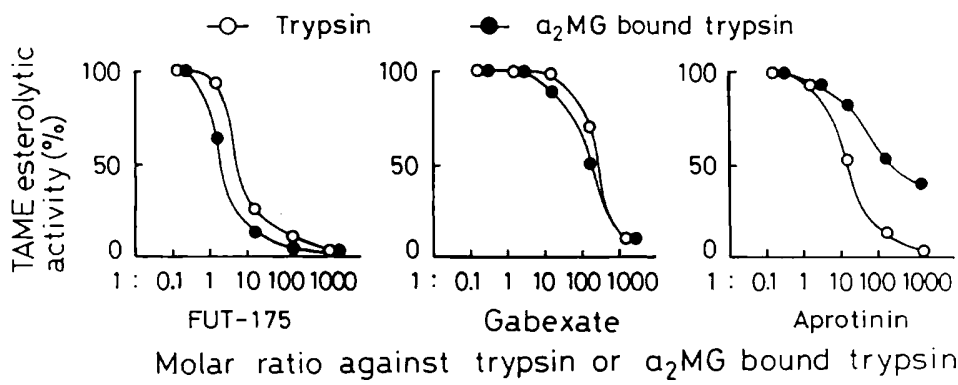

Fig. 2. Inhibitory effects of FUT-175, gabexate and aprotinin on the esterolytic activity of trypsin and its complex with $\alpha_{2}$-macroglobulin $\left(\alpha_{2} M G\right)$. Excess amount of $\alpha_{2}$-macroglobulin was added to trypsin. The molar ratio indicates the ratio of each drug to trypsin ( MW 23300) itself and trypsin existing in the $\alpha_{2}$-macroglobulin-trypsin complex. The molecular weights of the drugs are as follows: FUT-175: 540, gabexate: 417, and aprotinin: 6512 (10800 KIU/mg solid).

Table 3. Effects of FUT-175, gabexate and aprotinin on the enzyme activities in the pancrease with experimental acute pancreatitis

\begin{tabular}{|c|c|c|c|c|c|}
\hline \multirow{2}{*}{ Drug } & \multirow{2}{*}{$\begin{array}{c}\text { Dose } \\
(\mu \mathrm{g} / \mathrm{kg} / \mathrm{min})\end{array}$} & \multicolumn{3}{|c|}{ Protease activity } & \multirow{2}{*}{$\begin{array}{l}\mathrm{PLA}_{2} \text { activity } \\
\text { Phosphatidyl- } \\
\text { choline }(\mathrm{U} / \mathrm{ml})\end{array}$} \\
\hline & & $\begin{array}{c}\text { BocPheSerArgMCA } \\
\left(\times 10^{-4} \mu \text { moles } / \mathrm{min} / \mathrm{ml}\right)\end{array}$ & $\begin{array}{c}\text { TAME } \\
(\mathrm{nmoles} / \mathrm{min} / \mathrm{ml})\end{array}$ & $\begin{array}{c}\text { Casein } \\
\text { (OD440 nm) }\end{array}$ & \\
\hline Normal & & $20 \pm \quad 4.7$ & $39 \pm 12.2$ & 0.0 & $0.1 \pm 0.03$ \\
\hline Control & & $2308 \pm 408.2$ & $511 \pm 29.3$ & $0.89 \pm 0.121$ & $1.7 \pm 0.35$ \\
\hline FUT-175 & 0.5 & $1715 \pm 223.6$ & $442 \pm 17.5$ & $1.01 \pm 0.019$ & $1.5 \pm 0.32$ \\
\hline & 5 & $1718 \pm 353.6$ & $388 \pm 28.5^{*}$ & $0.97 \pm 0.094$ & $1.1 \pm 0.24$ \\
\hline & 50 & $319 \pm 96.7^{* *}$ & $211 \pm 56.5^{* *}$ & $0.41 \pm 0.132^{*}$ & $0.7 \pm 0.33$ \\
\hline Gabexate & 500 & $1602 \pm 500.0$ & $451 \pm 36.0$ & $0.80 \pm 0.110$ & $1.6 \pm 0.27$ \\
\hline Aprotinin & $2500^{\dagger}$ & $1604 \pm 408.2$ & $385 \pm 33.4^{*}$ & $0.97 \pm 0.065$ & $1.4 \pm 0.25$ \\
\hline
\end{tabular}

The drugs were infused intravenously. At $3 \mathrm{hr}$ after the induction of pancreatitis, the pancreas was removed, and the enzyme activities in the pancreas were measured. Each value represents the mean $\pm S$. E. of 6 rats. Significantly different from the control group at ${ }^{*} P<0.05,{ }^{*} P<0.01$ (Student's $t$-test). $\dagger \mathrm{KIU} / \mathrm{kg} / \mathrm{min}$

$1 / \mathrm{g} / \mathrm{kg} / \mathrm{min}$.

Furthermore, FUT-175 decreased the esterolytic activity of protease toward TAME dose-dependently at $0.5-50 \mu \mathrm{g} / \mathrm{kg} / \mathrm{min}$. To the caseinolytic activity of protease. FUT-175 showed almost no effects at 0.5 and $5 \mu \mathrm{g} /$ $\mathrm{kg} / \mathrm{min}$, but exhibited a significant suppression at a dose of $50 \mu \mathrm{g} / \mathrm{kg} / \mathrm{min}$.

FUT-175 also suppressed phospholipase $\mathrm{A}_{2}$ activity dose-dependently at $0.5-50 \mathrm{~kg} /$ $\mathrm{kg} / \mathrm{min}$. Gabexate, $500 / \mathrm{kg} / \mathrm{kg} / \mathrm{min}$, and aprotinin, $2500 \mathrm{KIU} / \mathrm{kg} / \mathrm{min}$, respectively, showed a slight suppressive effect on the trypsin activity; however, they had no suppressive effect on caseinolytic activity and phospholipase $\mathrm{A}_{2}$ activity. Aprotinin also suppressed esterolytic activity (Table 3 ).
2) Effect on enzyme activity in the plasma in experimental acute pancreatitis: In rats of the normal group, the trypsin activity measured with BocPheSerArgMCA was not observed in the plasma. On the other hand, it was clearly observed in the plasma in rats of the control group in which the pancreatitis was induced. At doses of $0.5-50 \mu \mathrm{g} / \mathrm{kg} / \mathrm{min}$. FUT-175 suppressed the trypsin activity significantly and dose-dependently. The effect of $500 \mu \mathrm{g} / \mathrm{kg} / \mathrm{min}$ of gabexate on trypsin activity in the plasma was almost the same as that of $0.5 \mu \mathrm{g} / \mathrm{kg} / \mathrm{min}$ of FUT-175. The effect of aprotinin, $2500 \mathrm{KIU} / \mathrm{kg} / \mathrm{min}$, was almost the same as that of FUT -175 of $50 \mu \mathrm{g} / \mathrm{kg} / \mathrm{min}$.

The amylase in the plasma was present at a high level in rats of the control group as 
Table 4. Effects of FUT-175, gabexate and aprotinin on the enzyme activities in the plasma with experimental acute pancreatitis

\begin{tabular}{lccc}
\hline Drug & $\begin{array}{c}\text { Dose } \\
(\mu \mathrm{g} / \mathrm{kg} / \mathrm{min})\end{array}$ & $\begin{array}{c}\text { Protease activity } \\
\text { BocPheSerArgMCA } \\
\left(\times 10^{-4} \mu \mathrm{moles} / \mathrm{min} / \mathrm{ml}\right)\end{array}$ & $\begin{array}{c}\text { Amylase activity } \\
(\mathrm{U} / \mathrm{d})\end{array}$ \\
Normal & & $-.4 \pm 0.04$ & $1478 \pm 175.0$ \\
Control & 0.5 & $21.6 \pm 3.77$ & $3216 \pm 250.0$ \\
FUT-175 & 5 & $13.6 \pm 1.65$ & $3124 \pm 242.5$ \\
& 50 & $8.9 \pm 2.28^{*}$ & $2895 \pm 267.3$ \\
Gabexate & 500 & $5.3 \pm 1.05^{* *}$ & $2745 \pm 288.7$ \\
Aprotinin & $2500+$ & $16.3 \pm 2.51$ & $3009 \pm 189.0$ \\
\hline
\end{tabular}

The drugs were infused intravenously. At $3 \mathrm{hr}$ after the induction of pancreatitis, the blood sample was removed, and the enzyme activities in plasma were measured. Each value represents the mean $\pm S . E$. of 6 rats. Significantly different from the control group at ${ }^{*} P<0.05,{ }^{*} P<0.01$ (Student's $t$-test). $+\mathrm{KIU} / \mathrm{kg} / \mathrm{min}$

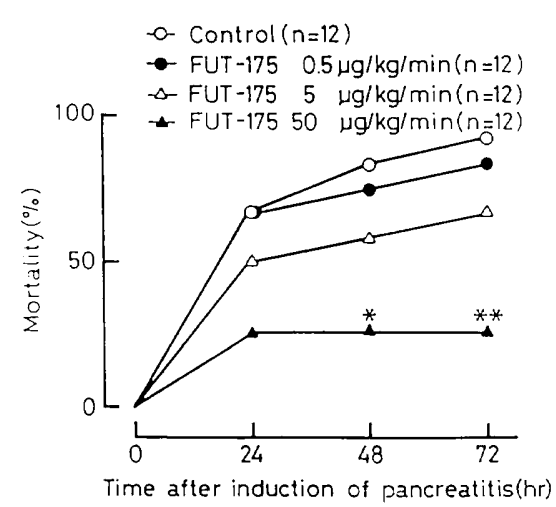

Fig. 3. Protective effect of FUT-175 on the mortality of rats with experimental acute pancreatitis. Groups of 12 rats were used. The drugs were infused intravenously. Significantly different from the control group at ${ }^{*} P<0.05,{ }^{*} P<0.01\left(\chi^{2}\right.$-test $)$.

well as in rats of the normal group. FUT-175 tended to inhibit an increase in amylase activity at doses of $0.5-50 \mu \mathrm{g} / \mathrm{kg} / \mathrm{min}$. On the other hand, neither gabexate nor aprotinin showed inhibitory effects on the elevation of amylase activity at doses of 500 $\mu \mathrm{g} / \mathrm{kg} / \mathrm{min}$ and $2500 \mathrm{KIU} / \mathrm{kg} / \mathrm{min}$, respectively (Table 4).

3) Protective effect of FUT-175 against deaths of rats with experimental acute pancreatitis: As shown in Fig. 3, FUT-175 exhibited a significant and dose-dependent lowering of the mortality of rats with acute pancreatitis at doses of $0.5-50 \mu \mathrm{g} / \mathrm{kg} / \mathrm{min}$.

\section{Discussion}

Previously, we reported that FUT-175 inhibited an increase in the blood trypsin activity and lowered the mortality in the experimental acute pancreatitis in rats and rabbits (3). In the previous experiments, however, we did not study the effects of FUT175 on enzyme activities in the pancreas. Thus, in the present study, we carried out investigations mainly focusing on the pancreas, using enterokinase for inducing the pancreatitis in place of the trypsin used in the previous experiments. In addition, in the present study, we investigated the effect of FUT-175 on the activity of trypsin in the $\alpha_{2}$ macroglobulin-complexed form more precisely as an extention of the previous study (2).

In in vitro experiments, inhibitory effects of FUT-175, gabexate and aprotinin on protease activities in the pancreatic enzyme preparation were investigated by adding a test drug to the preparation after or during activation by enterokinase. The substrates used were BocPheSerArgMCA for trypsin. TAME as an ester-type substrate and azocasein as a natural substrate.

The substrates used were found not to be cleaved by the pancreatic enzyme preparation before activation by enterokinase nor by enterokinase itself. FUT-175 and aprotinin 
inhibited protease activities in the activated pancreatic enzyme preparation regardless of being added to the preparation after or during activation by enterokinase. While gabexate inhibited protease activities with IC50 values of $10^{-5}-10^{-7} \mathrm{M}$ when added to the enzyme preparation after activation by enterokinase, it showed no inhibitory effects when added to the preparation during activation by enterokinase, as evidenced by IC50 values as high as greater than $10^{-4} \mathrm{M}$. As to inhibitory effects of test drugs on enterokinase itself, the findings of the present study demonstrated that FUT-175 inhibited it with a moderate potency with an IC50 value of $1.5 \times 10^{-6} \mathrm{M}$, gabexate had no inhibitory activity, and aprotinin inhibited it with very low potency with an IC50 value of $4000 \mathrm{KIU} / \mathrm{ml}$, being consistent with the finding by Ohnishi et al. (10) that aprotinin did not inhibit the enterokinase activity at concentrations up to $3000 \mathrm{KIU} / \mathrm{ml}$.

FUT-175 and gabexate have ester-linkages in their molecules. Nakahara (11) has described that gabexate completely loses its inhibitory effect on kallikrein after $10 \mathrm{~min}$ incubation with plasma at $37^{\circ} \mathrm{C}$. On the other hand. Aoyama et al. (2) have shown that FUT-175 is fairly stable in serum. Aprotinin which is a peptide has good chemical stability. Therefore, it may be considered that the inhibitory effects of these drugs on protease activities in the pancreatic enzyme preparation is a composite manifestation of several factors such as inhibitory activity on the activated protease, inhibitory activity on enterokinase and chemical stability of test drugs in the reaction mixture.

There are two proteins in human blood, $\alpha_{1}$ antitrypsin and $\alpha_{2}$-macroglobulin, which have inhibitory activity against proteases. $\alpha_{2}$ Macroglobulin, however, possesses some unique properties. Namely. Rinderknech and Geokas (12) have reported that trypsinogen and chymotrypsinogen are activated by $\alpha_{2-}$ macroglobulin bound trypsin. $\alpha_{2}$-Macroglobulin strongly inhibits the protease activity, but not esterolytic or amidase activity toward a synthetic low-molecular substrate, of enzymes such as trypsin (13). Furthermore, it is known that SBTI (MW 20100) does not inhibit the $\alpha_{2}$-macroglobulin bound trypsin activity toward low molecular weight substrates (14). Then, we investigated the effect of FUT-175, gabexate and aprotinin on $\alpha_{2}$-macroglobulin bound trypsin. FUT-175 and gabexate inhibited the $\alpha_{2}$-macroglobulin bound trypsin activity as well as free trypsin, but aprotinin showed weaker inhibitory effect on the activity of the complex than on that of free trypsin. These data suggest that the inhibitory activity of test drugs on $\alpha_{2}$ macroglobulin bound trypsin is influenced by its molecular size.

In an in vivo experiment, we examined the effect of FUT-175, gabexate and aprotinin on enzyme activities in the pancreas and plasma in experimental acute pancreatitis. The doses of drugs were determined according to the previous report (3).

In rats of the normal group, which were injected saline into pancreas, the enzyme activities except amylase activity were too low to be measured in the pancreas and plasma. On the other hand, the protease activities and phospholipase $A_{2}$ activity were obviously elevated in rats of the control group which were injected the mixture of enterokinase and sodium taurocholate into the pancreas.

Creutzfeldt et al. (4) have described that the typical picture of pancreatitis in humans is that it is not produced by the action of trypsin itself, but by the action of phospholipase A. FUT-175, 0.5-50 $\mu \mathrm{g} / \mathrm{kg} / \mathrm{min}$, suppressed not only phospholipase $A_{2}$ activity but also protease activities elevated in both the pancreas and plasma following induction of the experimental acute pancreatitis. It was revealed that FUT-175 suppressed the trypsin activities in the pancreas and in the plasma to the same extent. Gabexate, $500 \mu \mathrm{g} / \mathrm{kg} / \mathrm{min}$, suppressed the trypsin activities in the pancreas and plasma, but the extent of suppression was about the same as that of $0.5-5 \mu \mathrm{g} / \mathrm{kg} / \mathrm{min}$ of FUT-175. These data did not reflect their trypsin inhibiting effects in vitro (FUT-175, $3.8 \times 10^{-8} \mathrm{~g} / \mathrm{ml}=$ gabexate, $\left.2.6 \times 10^{-7} \mathrm{~g} / \mathrm{ml}\right)$. It is known that FUT-175 has fairly good chemical stability (2), and gabexate is chemically unstable (11). The discrepancy between in vitro data and in vivo data may be explained by the difference in stability of 
FUT-175 and of gabexate in the pancreas and in the blood. Aprotinin, $2500 \mathrm{KIU} / \mathrm{kg} / \mathrm{min}$, suppressed the protease activities in the pancreas and plasma, although the extent of suppression of trypsin in the plasma was more potent than those in the pancreas. The extent of suppression of trypsin in the plasma was about the same as that of $50 \mu \mathrm{g} / \mathrm{kg} / \mathrm{min}$ of FUT-175. These data reflect the trypsin inhibiting effects in vitro (FUT-175, 3.8 $\times 10^{-8}$ $\mathrm{g} / \mathrm{ml}=$ aprotinin, $0.54 \mathrm{KIU} / \mathrm{ml}$ ).

Previously, we reported that FUT-175 reduced dose-dependently the mortality of rats in trypsin-induced experimental acute pancreatitis (3). In the same report, 2500 $\mathrm{KIU} / \mathrm{kg} / \mathrm{min}$ of aprotinin was shown to exert the same effect on the mortality of rats as that of $50 \mu \mathrm{g} / \mathrm{kg} / \mathrm{min}$ of FUT-175. In the present study, FUT- 175 reduced the mortality of rats to the same extent as described in the previous report. It is known that trypsin released into the blood causes hypotension and shock (6).

According to the previous report and the present study, it is suggested that the protective effects of FUT-175 and aprotinin against the deaths of rats following induction of the experimental acute pancreatitis result from the suppression of leakage of enzymes, i.e., trypsin, into the blood and enzyme activities in the blood.

In conclusion, (1) FUT-175 inhibited the pancreatic protease activities in vitro; (2) FUT-175 inhibited the $\alpha_{2}$-macroglobulin bound trypsin activity: and (3) FUT-175 suppressed the protease activities and phospholipase $A_{2}$ activity in vivo in the pancreas in experimental acute pancreatitis with higher potency than gabexate, and differently from the action of aprotinin; FUT-175 suppressed the trypsin activities in the pancreas and in the plasma to the same extent. These data strongly support that FUT-175 is clinically useful in the therapy of acute pancreatitis.

\section{References}

1 Fujii, S. and Hitomi, Y.: New synthetic inhibitors of $\mathrm{C} 1 \vec{r}, \mathrm{C} 1$ esterase, thrombin, plasmin, kallikrein and trypsin. Biochim. Biophys. Acta 661, 342345 (1981)
2 Aoyama, T., Ino, Y., Ozeki, M., Oda, M., Sato, T., Koshiyama, Y., Suzuki, S. and Fujita, M.: Pharmacological studies of FUT-175, nafamstat mesilate. I. Inhibition of protease activity in in vitro and in vivo experiments. Japan. J. Pharmacol. 35, 203-227 (1984)

3 Iwaki, M., Ozeki, M., Sato, T., Suzuki, K., Motoyoshi, A., Suzuki, S., Fujita, M. and Aoyama, T.: Pharmacological studies of FUT. 175, nafamstat mesilate. II. Effects on experimental acute pancreatitis. Folia Pharmacol. Japon. 84, 363-372 (1984) (Abs. in English)

4 Creutzfeldt, W. and Schmidt, H.: Aetiology and pathogenesis of pancreatitis (Current concepts). Scand. J. Gastroenterol. Supp. 6, 47-62 (1970)

5 Beck, J.T., Pinter, E., Solymar, J., McKenna, R.D. and Ritchie, A.C.: The role of pancreatic enzymes in the pathogenesis of acute pancreatitis. 11. The fate of pancreatic proteolytic enzymes in the course of acute pancreatitis. Gastroenterology 43, 60-70 (1962)

6 Katz, W., Silverstein, M., Kobold, E.E. and Thal, A.P.: Trypsin release, kinin production and shock. Relationship in experimental and human pancreatitis. Arch. Surg. 89, 322-331 (1964)

7 Barns, R.J. and Elislie, R.G.: The effects of $\mathrm{Ca}^{2+}$ on porcine enteropeptidase activity. Biochim. Biophys. Acta 321, 624-631 (1973)

8 Roberts, P.S.: Measurement of the rate of plasmin action on synthetic substrates. J. Biol. Chem. 232, 285-291 (1958)

9 Hansson, K., Lundh, G. and Stenram, U.: Morphological and secretory studies in experimentally induced pancreatitis in rats. Acta Chir. Scand. 121, 274-283 (1961)

10 Ohnishi, H., Kosuzume, H., Ashida, Y., Kato, K., Suzuki, Y. and Honjo, I.: Therapeutic effects of human urinary trypsin inhibitor on acute experimental pancreatitis. Folia Pharmacol. Japon. 81, 235-244 (1983) (Abs. in English)

11 Nakahara, H.: Inhibitory effects of aprotinin and gabexate mesilate on human plasma kallikrein. Arzneimittelforsch. 33, 969-971 (1983)

12 Rinderknecht, $H$. and Geokas, M.C.: On the physiological role of $\alpha_{2}$-macroglobulin. Biochim. Biophys. Acta 295, 233-244 (1973)

13 Barrett, A.J. and Starkey, P.M.: The interaction of $\alpha_{2}$-macroglobulin with proteases. Biochem. J. 133, 709-724 (1973)

14 Nagasawa, S., Han, B.H., Sugihara, H. and Suzuki, T.: Studies on macroglobulin in bovine plasma. J. Biochem. 67, 821-832 (1970) 